\title{
Herd- and cow-level risk factors associated with subclinical mastitis in dairy farms from the High Plains of the northern Antioquia, Colombia
}

\author{
N. F. Ramírez, ${ }^{* 1}$ G. Keefe,† I. Dohoo,† J. Sánchez,† O. Arroyave, ${ }^{*}$ J. Cerón,‡ M. Jaramillo,‡ and L. G. Palacio* \\ *Epidemiology and Public Health, Centauro Research Group, Faculty of Agricultural Sciences, University of Antioquia, Calle 70 No. 52-21, C.P. \\ 050010 Medellín, Colombia \\ †Centre for Veterinary Epidemiological Research, Atlantic Veterinary College, University of Prince Edward Island, Charlottetown, \\ Prince Edward Island, Canada C1A 4P3 \\ ‡Cooperativa Colanta Ltda., CRA 64C, 72-160 Medellín, Colombia
}

\section{ABSTRACT}

Mastitis is the main disease entity affecting dairy farms in the Colombian High Plains of northern Antioquia, Colombia. However, no previous epidemiologic studies have determined the characteristics that increase the risk of infection in this region, where manual milking is still the prevailing system of milking. A 24mo longitudinal study was designed to identify the predominant mastitis pathogens and important herd- and cow-level risk factors. Monthly visits were made to 37 commercial dairy farms to collect herd- and cow-level data and milk samples. Herd size varied from 6 to 136 cows (mean 37.0, median 29). Herd-level factors included type of milking system (manual or mechanical) and a range of management practices recommended by the National Mastitis Council (Madison, WI) to prevent mastitis. Individual cow-level risk factors included parity, stage of lactation, breed, udder hygiene, and lameness. A logistic regression analysis was used to investigate associations between herd- and cow-level risk factors with the presence of subclinical mastitis and infection caused by Streptococcus agalactiae at the quarter level. A quarter was considered to have subclinical mastitis if it had a positive California Mastitis Test and was subsequently confirmed to have a somatic cell count of $\geq 200,000$ cells $/ \mathrm{mL}$. Any cow with one or more quarters with subclinical mastitis was considered to have subclinical mastitis at the cow level. Using 17,622 cow observations, the mean prevalence of subclinical mastitis at the cow level was $37.2 \%$ (95\% confidence interval: $31.2,43.3)$ for the first month and did not substantially change throughout the study. The predominant microorganisms isolated from quarters meeting the subclinical mastitis definition were contagious pathogens, including Strep. agalactiae (34.4\%), Corynebacterium spp. (13.2\%), and Staphylococcus aureus

Received March 14, 2013.

Accepted March 16, 2014.

${ }^{1}$ Corresponding author: nicoramirez2010@gmail.com
(8.0\%). Significant variables associated with subclinical mastitis risk at the quarter level included being a purebred Holstein cow, higher parity, and increased months in milk. Variables that were protective for mastitis risk included being a crossbreed cow and adequate premilking udder hygiene. Significant variables associated with Strep. agalactiae infection were higher parity, increased months in milk, and manual milking. Variables that were protective were postmilking teat dipping and adequate cleaning of the udder. The results highlight the importance of hygiene practices in contagious mastitis control in manually milked herds.

Key words: mastitis prevalence, manual milking, dairy cow

\section{INTRODUCTION}

Mastitis is globally considered to be the most costly infectious disease in the dairy industry (Fetrow et al., 1991). In the United States alone, calculated loses were approximately $\$ 2$ billion per year during the 1990s (Harmon, 1994) and for countries such as Germany, recent estimates attribute losses of $€ 200 /$ cow per year (Kramer et al., 2009). Economic data for Colombia are not available. However, studies using the California Mastitis Test (CMT) and SCC as tools to diagnose subclinical mastitis (SM) have reported prevalence values that range from 19.9 to $51.3 \%$ (Calderon and Rodríguez, 2008; Pinzon et al., 2009; Trujillo et al., 2011). Other authors have recently reported that contagious mastitis caused by Streptococcus agalactiae was associated with a $70 \%$ increase in herd SCC and a near doubling of raw milk bacteria counts in Colombia (Keefe et al., 2011).

Risk factors for SM, including the importance of postmilking teat disinfection, have been established for many years (Neave et al., 1969). Prevention of the spread of pathogens from cow to cow implies that the teats must be kept free of pathogens. To this end, methods have been investigated, including the use of disinfectants, paper towels, or individual wash cloths; the 
wearing of rubber gloves by the milker; and the cleaning and disinfecting of the teat cup clusters before each cow is milked, together with postmilking disinfectant teat dips aimed at destroying any pathogens remaining on the teats after milking (Neave et al., 1969). One of the techniques used to monitor the level or occurrence of $\mathrm{SM}$ in herds or individual cows or quarters is to determine the SCC (Dohoo and Meek, 1982). Most practices having consistent associations with SCC were related to milking procedures: using automatic take-offs, using postmilking teat dipping (PMTD), milking problem cows last, yearly inspection of the milking system, and use of a technique to keep cows standing following milking; all were consistently associated with lower herd SCC (Dufour et al., 2011). Because the conditions leading to a high prevalence of mastitis are numerous, mastitis prevention programs should ideally be preceded by an assessment of the risk factors most relevant to the local industry. In the northern plains of Antioquia, Colombia, approximately $90 \%$ of producers still use manual milking, which is carried out directly on the pasture (Ramírez et al., 2009). Locally reported studies and anecdotal evidence suggest that bovine mastitis is undoubtedly the main disease entity affecting dairy cows in this area (Ramírez et al., 2001; Rodríguez et al., 2002). However, rigorous studies that identify the primary risk factors associated with subclinical mastitis are lacking in Colombia. In various cross-sectional studies conducted in Antioquia and the Bogota savannah, a positive association was observed between SM (as determined by positive CMT), parity, and mechanical milking (Ramírez et al., 2001). By contrast, no relationship was found with days in lactation (Ramírez et al., 2001). The main bacterial species isolated from mastitic Colombian cows have been Strep. agalactiae and Staphylococcus aureus, which accounted for 35 to $45 \%$ and 14 to $33 \%$ of infections, respectively (Rodríguez et al., 2002; Rodríguez, 2006). Because manual milking is the prevailing milking system in many parts of Colombia, we were interested in establishing the important risk factors associated with the prevalence of SM and infection by contagious pathogens in these herds.

The 2 objectives of this SM study were (1) to obtain overall and bacterial pathogen-specific prevalence estimates, and (2) to evaluate the major risk factors for SM in typical dairy farms of the High Plains region of Colombia.

\section{MATERIALS AND METHODS}

\section{Ethical Considerations}

This research was approved by the Ethics Committee for Animal Experimentation of the University of
Antioquia, Colombia (Act number 48, from December $12,2008)$.

\section{Herd Selection}

A convenience sample of 37 herds were selected from 3,049 registered dairy farms in 6 municipalities that make up the main dairy-specialized area of the High Plains of northern Antioquia, Colombia (Entrerrios, Belmira, Santa Rosa de Osos, San Jose de la Montaña, San Pedro de los Milagros, and Donmatias). Based on the inclusion criteria described below, 120 typical herds from the 6 municipalities were invited to participate, 99 accepted, 21 declined, and 37 were selected for sampling. The final 37 herds selected were those that best met the characteristics defined below. The number of herds selected in each municipality was proportional to the size of that area's dairy industry: Belmira $9 \%$ (3 herds), Donmatias 11\% (3 herds), Entrerrios 19\% (6 herds), San Jose 5\% (2 herds), San Pedro 24\% (8 herds), and Santa Rosa 32\% (10 herds). Within each municipality, herds were selected based on the following typical management conditions in the region, including 2 milkings a day, the use of pasture as the main source of feed, giving concentrate to the cows as a supplement at milking time, AI, breeds mainly composed of specialized dairy cows, on-farm cooling tanks, and proper cow identification. Other aspects taken into account to select the herds were easy road access and whether the owner was willing to collaborate in collection of samples. When it was necessary to replace one of the herds, investigators selected another herd from the list of eligible herds in that region that met the inclusion criteria. All cows in each herd selected were included in the study. Based on previous work that reported a cow-level prevalence estimate for SM of 34\% (Ramírez et al., 2001) and a desired precision of $\pm 5 \%$, the number of animals required for a single-point-in-time prevalence estimate was 324 cows (SPSS Statistics, version 21.0; IBM Corp., Armonk, NY). To adjust for the reality that true random sampling could not be conducted because of industry logistics and the fact that the level of herd clustering was not accounted for in this sample size calculation, the total number of cows sampled at any sampling time was approximately 700 cows. All the milking cows in each herd were sampled each time. The study started with 32 herds that met the inclusion criteria. However, 5 had to be replaced part-way through the study so data were obtained from 37 different herds.

\section{Visit Protocol}

All farms were visited once per month for a period of 2 yr (January 2009 to December 2010) to collect 
milk samples during the evening milking. At each herd visit, a CMT evaluation was performed on all milking cows greater than $4 \mathrm{~d}$ postpartum. The udder and teats were prepared by the farmer using the normal premilking routine. Subsequently, the first streams of milk were discarded before sample collection, and the CMT was performed as instructed by the manufacturer. Subsequently, for all quarters that had a positive or suspect CMT result, teat ends were disinfected with cotton swabs drenched in $70 \%$ alcohol, and duplicate milk samples (approximately $5 \mathrm{~mL}$ ) were taken. One of the samples was tested for SCC using the DeLaval Cell Counter (DeLaval, Stockholm, Sweden). The second sample was used for bacteriological culture (criteria below).

\section{Bacteriological Culture}

Any quarter that had a positive or suspect CMT result and was confirmed to have a SCC $\geq 200,000$ cells $/ \mathrm{mL}$ had a bacterial culture conducted. Both the SCC test and the bacterial culture of the samples were done at the Laboratory of Microbiology, School of Veterinary Medicine, University of Antioquia (Medellín, Colombia). Samples were cultured using standard laboratory methods (MacFaddin, 2000; Winn et al., 2006) Briefly, using a sterile calibrated loop $(0.01 \mathrm{~mL})$, milk samples were streaked on tripticase soy, chocolate, azida supplemented with 5\% sheep blood, MacConkey, and Sabouraud agar plates. Plates were incubated at $37^{\circ} \mathrm{C}$ and examined for bacterial growth at 24 and 48 $\mathrm{h}$, except for Sabouraud agar plates, which were incubated for $5 \mathrm{~d}$. Tests were performed for identification of the following microorganisms: Staph. aureus, CNS, Strep. agalactiae, Streptococcus uberis, Streptococcus dysgalactiae, Streptococcus pyogenes, Corynebacterium spp., Escherichia coli, Enterobacter aerogenes, Klebsiella spp., Pseudomonas spp., and yeast (Candida spp.). Bacteria were identified tentatively by gross colony morphology and Gram stain, and further confirmatory tests were used as necessary. Gram-positive cocci were tested for the presence of catalase to differentiate streptococci from staphylococci. The tube coagulase test was used to identify Staph. aureus and other coagulase-positive staphylococci from CNS. Positive cocci on both tests (catalase and coagulase) were tested with mannitol, DNase, and urea to differentiate Staph. aureus from other Staphylococcus, such as Staphylococcus intermedius. Gram-positive and catalase-negative cocci were identified as Streptococcus spp. and were classified by Christie, Atkins, Munch-Petersen (CAMP), esculin hydrolysis, bacitracin, and growth in $\mathrm{NaCl}(6.5 \%)$ tests. Gram-negative compatible colonies were tested with oxidase to classify them as fermenting and nonferment- ing bacteria and then typed by biochemical methods, such as lysine, triple sugar, Simmons citrate, sulfide indole motility (SIM), and urea. Where primary biochemical methods were inadequate, BBL Crystal Identification System (Becton Dickinson Co., Sparks, MD) was used to identify bacteria, such as Corynebacterium spp., Listeria spp., and nonfermenting gram-negative organisms. After morphological categorization on Sabouraud agar and Gram staining, the germ tube test was used to identify Candida albicans.

In this study, IMI was defined as the presence $(\geq 1$ colony) or absence of pathogens in the milk sample. The presence of 3 or more colony types was considered contamination and discarded from the analysis according to the National Mastitis Council guidelines (NMC, 1999).

\section{Case Definition}

A quarter was considered to have SM at a regular monthly visit if it had a CMT score of trace or higher and the subsequent SCC was $\geq 200,000$ cells $/ \mathrm{mL}$. A cow was classified as having SM if she had SM in one or more quarters.

For pathogen prevalence, a quarter was considered infected if it was diagnosed as having SM and 1 or 2 pathogens (according the IMI definition above) were isolated from the milk sample. Quarters that did not have a CMT score of trace or higher were not sampled and hence were classified as noninfected in analysis of the data. A cow was classified as infected if she had one or more quarters infected. Infection with Strep. agalactiae was the only type of infection analyzed in detail.

\section{Risk Factors}

The risk factors selected in this investigation focused mainly on the milking routine process. Selected cowand herd-level risk factors evaluated for relationships with mastitis susceptibility are shown in Tables 1 and 2 , respectively. Information was collected through questionnaires administered directly to the farmers on every visit and by direct observation of the milking and husbandry practices (questionnaires available from the first author upon request). Only variables that were consistently recorded (with few missing values) are shown. Questionnaires were administered by 1 of 4 technicians on a monthly basis. Technicians were trained before project initiation at the University of Antioquia farm, to ensure that recording was consistent. Variables such as herd size were not significant in the unconditional analysis. Other variables, such as dry cow therapy, were not analyzed because almost all of the herds reported that they were doing it (only one did not). Season was 
Table 1. Selected cow-level predictors evaluated as risk factors for both subclinical mastitis (SCC $\geq 200,000$ cells $/ \mathrm{mL}$ ) and Streptococcus agalactiae infection in 37 herds in Antioquia, Colombia

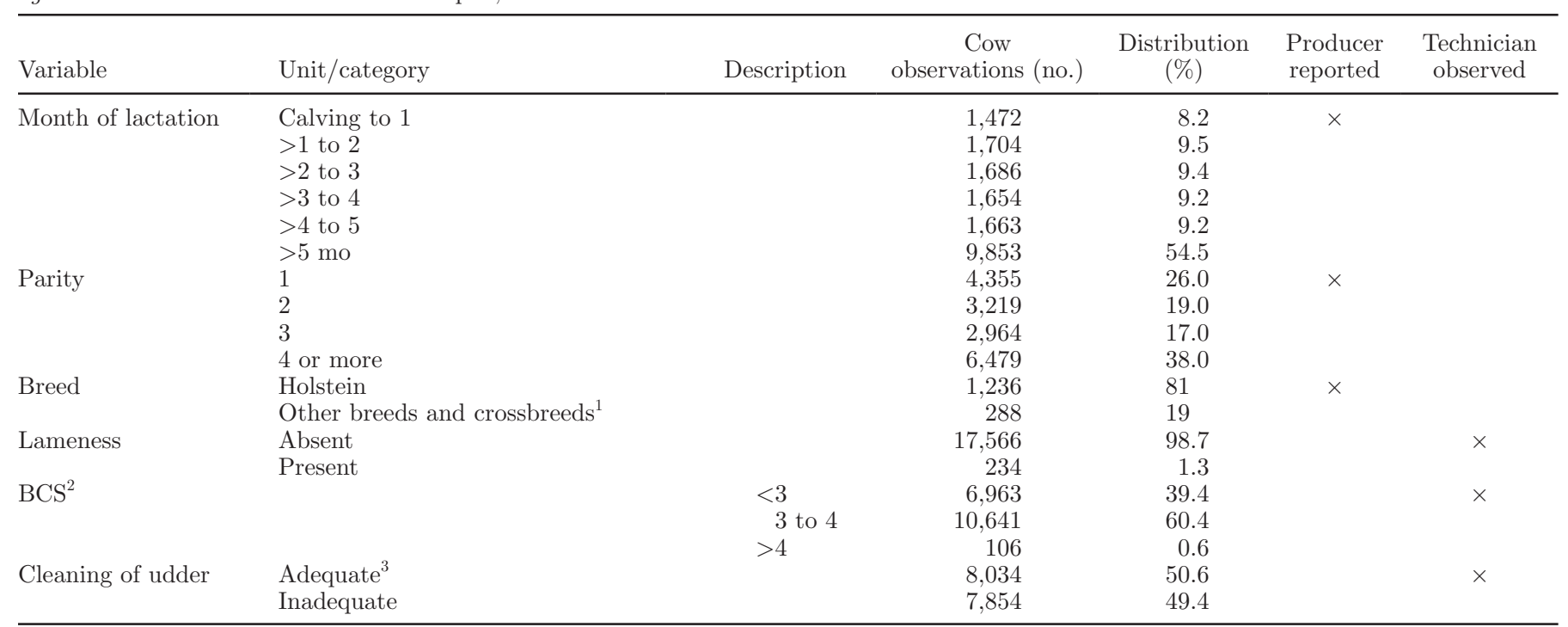

${ }^{1}$ Other breeds and crossbreeds included Ayrshire, Swedish Red, Swiss Brown, Jersey, and several crosses of Holstein with other breeds such as Jersey, Ayrshire, Angus, Blanco Orejinegro, Brahman, and Gir.

${ }^{2}$ According to the scale by Edmonson et al. (1989).

${ }^{3}$ No litter, mud, or other dirt was present before milking and after preparation of the udder.

not analyzed because temperature patterns are not related to calendar month, due to Colombia's proximity to the equator. Housing was not measured as a variable because all cows were on pasture.

\section{Statistical Analysis}

All data were entered into Excel worksheets (Microsoft Corp., Redmond, WA) and then exported to Stata 12.0 (StataCorp, 2011) for analysis. The data were examined for biologically implausible entries and any erroneous entries were removed or corrected. Descriptive statistics were computed for all variables of interest. Variables with more than $30 \%$ missing values were deleted. Pearson and Spearman correlation analysis was executed for continuous and categorical variables, respectively. When a correlation coefficient $>0.30$ between a pair of variables was found, only one was selected for inclusion in the model based on the following criteria: biological plausibility, fewer missing observations, reliability of measurement.

Observations were stratified by municipality and sampling weights were computed as the inverse of the probability of the herd being selected in the municipality (i.e., number of herds in municipality divided by number of herds selected in municipality). The clustering and repeated-measures structure of the collected data (multiple observations from quarters that were clustered within cows that were clustered within herds) were taken into account by using variance linearization estimation procedures, with herds identified as the primary clustering unit (this is equivalent to using robust standard errors, which are allowed to vary across clusters herds).

Unconditional associations between each risk factor and the outcomes of interest-SM and Strep. agalactiae infection - were computed, and associations with $P \leq$ 0.15 were retained for consideration in multivariable models.

Multivariable logistic regression models were constructed with cow-level variables remaining in the model if they had a Wald test $P \leq 0.05$ and herdlevel variables being retained if $P \leq 0.10$. Biologically plausible 2-way interactions between pairs of predictors were evaluated using a Wald test to compare models with and without the interaction term included. In the SM model, analysis was made for an interaction between breed and DIM; for the Strep. agalactiae model, analysis was made for an interaction between adequate cleaning of udder and PMTD. The potential confounding effect of breed was evaluated by refitting the final models with breed omitted to see if the coefficients for other predictors changed substantially. Results from the final models are presented as odds ratios (OR) along with their $95 \%$ CI. Model fit was assessed using the Hosmer-Lemeshow goodness of fit test.

\section{RESULTS}

\section{Herd Characteristics and Practices}

The study started with 32 herds that met the inclusion criteria. However, 5 had to be replaced part-way 
Table 2. Selected herd-level predictors considered as risk factors for both subclinical mastitis (SCC $\geq 200,000$ cells/mL) and Streptococcus agalactiae infection

\begin{tabular}{|c|c|c|c|c|}
\hline Variable $^{1}$ & Unit/category & Description & $\begin{array}{l}\text { Observations } \\
\quad \text { (no.) }\end{array}$ & $\begin{array}{l}\text { Distribution } \\
\quad(\%)\end{array}$ \\
\hline \multirow[t]{2}{*}{ Type of milking } & Manual & & 580 & 77.7 \\
\hline & Machine & & 167 & 22.3 \\
\hline \multirow[t]{3}{*}{ Teat washing } & Not washing & & 649 & 87.3 \\
\hline & Washing and drying & The milkers wash teats with water and dry it with a piece of paper or cloth & 85 & 11.4 \\
\hline & Washing and not drying & The milkers wash teats with water but without drying it & 9 & 1.2 \\
\hline \multirow{2}{*}{ Hand prewashing } & No & & 545 & 83.0 \\
\hline & Yes & The milkers washed their hands at the beginning to milk the herd & 112 & 17.0 \\
\hline \multirow{2}{*}{ Hands washes between cows } & No & & 497 & 90.0 \\
\hline & Yes & The milkers washed their hands before beginning to milk each cow & 57 & 10.0 \\
\hline \multirow[t]{4}{*}{ No. of people milking } & 1 & & 261 & 34.9 \\
\hline & 2 & & 393 & 52.5 \\
\hline & 3 & & 91 & 12.2 \\
\hline & 4 & & 4 & 0.53 \\
\hline \multirow{2}{*}{ Milking by the owner } & No & & 445 & 61.63 \\
\hline & Yes & & 277 & 38.37 \\
\hline \multirow[t]{2}{*}{ Milker changed in the last month } & No & & 575 & 88.9 \\
\hline & Yes & & 72 & 11.3 \\
\hline \multirow{3}{*}{ Premilking teat dipping } & None & & 227 & 30.51 \\
\hline & Inadequate & $\begin{array}{l}\text { Not recommended chemical type, a concentration different than manufacturer } \\
\text { recommendation, or not enough contact time on the teat }(<30 \mathrm{~s})\end{array}$ & 514 & 69.0 \\
\hline & Adequate & $\begin{array}{l}\text { Defined as using a recommended chemical type at a concentration } \\
\text { recommended by the manufacturer with at least } 30 \mathrm{~s} \text { of contact time. }\end{array}$ & 3 & 0.4 \\
\hline \multirow[t]{2}{*}{ Postmilking teat dipping } & None or inadequate & $\begin{array}{l}\text { Inadequate: Not recommended chemical type or at a concentration } \\
\text { different than manufacturer recommendation }\end{array}$ & 117 & 15.7 \\
\hline & Adequate & $\begin{array}{l}\text { Recommended chemical type and at a concentration recommended } \\
\text { by the manufacturer }\end{array}$ & 626 & 84.3 \\
\hline
\end{tabular}

글 ${ }^{1}$ All risk factors were as observed by the technician except for "milker changed in the last month," which was reported by the producer. 
through the study so data were obtained from 37 different herds, whose characteristics are summarized in Table 3. The 5 herds left the study for the following reasons: farmer discontinued dairying in represented region (2), researcher was unable to access safely (2), and farmer was noncompliant with study protocol (1). On average, each herd in the study had 20 monthly visits. Thirty (81\%) used manual milking (27 directly on the pasture and 3 in milking parlor) and 7 used mechanical milking in the parlor, which is consistent with the type of milking in the represented zone. Evaluation of CMT was made on 1,662 unique cows with 17,622 cow samplings and 71,915 quarter samples. On average, each cow in the study was sampled 10.6 times for the CMT test.

\section{CMT and Quarter-Level SM}

Out of 71,915 total quarter samples examined, 11,842 (16.5\%) had a CMT result of trace or greater. That figure included repeated sampling of the same quarter. Of these 11,842 samples, 11,312 had SCC $\geq 200,000$ cells/mL, giving an apparent prevalence of SM at the quarter level of $15.7 \%$, with a monthly range from 12.2 to $19.9 \%$.

\section{Bacterial Cultures}

Culture results were obtained from the 11,312 samples with positive CMT and $\mathrm{SCC} \geq 200,000$ cells $/ \mathrm{mL}$ from 1,662 cows on 37 dairy farms. Eighty-three quarter milk samples were considered contaminated and were discarded from the analysis because they had growth of 3 or more colony types. A diagnosis of mixed etiology was made in 776 cases $(6.9 \%)$ when 2 pathogens were identified in the milk sample. The overall results for all microorganisms identified are shown in Table 4 .
The most prevalent SM pathogen isolated was Strep. agalactiae (34.4\% of isolates), followed by CNS and Corynebacterium spp. in 17.6 and $13.2 \%$ of the isolates, respectively. No growth occurred in 3,441 (30.4\%) of the SM samples.

\section{Geometric Mean of Quarter SCC by Pathogen and Cow-Level SM}

Geometric mean and confidence interval of quarter SCC by pathogen are shown in Table 4. Streptococcus agalactiae, Strep. pyogenes, Strep. dysgalactiae, and Strep. uberis increased the quarter SCC to 1,122, 1,323, 1,235 , and $1,366 \times 10^{3}$ cells $/ \mathrm{mL}$, respectively. The overall monthly SM prevalence was $36.8 \%$ and did not vary significantly by month.

\section{Risk Factors for SM at the Quarter Level}

Table 5 outlines significant predictors of quarter-level infection using logistic regression. The odds of having a quarter case of mastitis were significantly lower (OR $=0.7)$ in crossbreed cows and other breeds versus Holsteins. Two cow-level factors that showed strong associations with the presence of SM quarters were parity and stage of lactation. As cows aged, risk of SM increased continuously. For example, the odds of a cow of parity $\geq 4$ having SM was 3.4. Similarly, as month of lactation progressed, cows had increased odds of having cases of SM at the quarter level. Biologically plausible interactions of predictor variables were assessed and found to be nonsignificant. From these analysis, the interaction between breed and DIM was strongest $(P$ $=0.11$; data not shown) but did not meet criteria to be retained in the final model. The Hosmer-Lemeshow goodness of fit test suggested that the model fit the data $(P=0.7)$.

Table 3. Descriptive summary of the dairy cows and herds participating in a study to assess risk factors associated with subclinical mastitis ( $\mathrm{SCC} \geq 200,000$ cells $/ \mathrm{mL}$ ) in the high plains of Antioquia, Colombia

\begin{tabular}{|c|c|c|c|c|}
\hline Variable & $\begin{array}{c}\text { Observations } \\
\text { (no.) }\end{array}$ & Mean \pm SD & Minimum & Maximum \\
\hline \multicolumn{5}{|l|}{ Herd variable } \\
\hline Herd size ${ }^{1}$ & 773 & $25.6 \pm 16.7$ & 6 & 136 \\
\hline Milking personnel & 749 & $1.7 \pm 0.7$ & 1 & 4 \\
\hline \multicolumn{5}{|l|}{ Cow variable } \\
\hline Parity & 17,005 & $3.2 \pm 2.1$ & 1 & 15 \\
\hline Milk production $(\mathrm{L} / \mathrm{d})^{2}$ & 17,692 & $17.8 \pm 6.3$ & 4 & 50 \\
\hline Days in lactation & 18,032 & $181.0 \pm 124.2$ & 4 & 966 \\
\hline $\mathrm{BCS}(1 \text { to } 5)^{3}$ & 17,710 & $3.0 \pm 0.4$ & 1 & 5 \\
\hline Dairy concentrate $(\mathrm{kg} / \mathrm{d})^{4}$ & 17,072 & $4.9 \pm 2.1$ & 1 & 13 \\
\hline
\end{tabular}


Table 4. Pathogens isolated and quarter geometric mean SCC by pathogen from 7,954 culture positive milk samples collected from 1,662 dairy cows participating in the assessment of risk factors associated with subclinical mastitis ( $\mathrm{SCC} \geq 200,000$ cells/mL) in the High Plains of Antioquia, Colombia

\begin{tabular}{lrccc}
\hline & $\begin{array}{c}\text { No. of } \\
\text { isolates }\end{array}$ & $\begin{array}{c}\text { Percent } \\
\text { of total } \\
\text { isolates }\end{array}$ & $\begin{array}{c}\text { Geometric mean SCC } \\
\text { (cells/mL } \times 1,000)\end{array}$ & $95 \%$ CI \\
\hline Ptreptococcus agalactiae & 2,977 & 34.4 & 1,122 & $1,086-1,159$ \\
CNS & 1,525 & 17.6 & 609 & $584-636$ \\
Corynebacterium spp. & 1,142 & 13.2 & 584 & $558-611$ \\
Streptococcus pyogenes & 958 & 11.1 & 1,323 & $1,245-1,406$ \\
Staphylococcus aureus & 691 & 8.0 & 810 & $763-861$ \\
Streptococcus dysgalactiae & 453 & 5.2 & 1,235 & $1,130-1,349$ \\
Staphylococcus intermedius & 250 & 2.9 & 882 & $792-982$ \\
Streptococcus uberis & 192 & 2.2 & 1,366 & $1,187-1,573$ \\
Escherichia coli & 160 & 1.9 & 675 & $565-805$ \\
Others & 104 & 1.2 & 1,003 & $830-1,214$ \\
Klebsiella & 104 & 1.2 & 967 & $732-1,278$ \\
Candida spp. & 62 & 0.7 & 1,067 & $743-1,531$ \\
Enterobacter & 29 & 0.3 & 965 & $649-1,434$ \\
Total & $8,647^{2}$ & 100.0 & & \\
\hline Th & & &
\end{tabular}

${ }^{1}$ This group includes sporadic rare pathogens such as Geotrichum spp., Trichosporum spp., Citrobacter freundii, Pseudomonas fluorescens.

${ }^{2}$ Total is greater than sample numbers because 776 samples yielded 2 bacterial species. Eighty-three samples yielded contaminated results (3 or more colony types).

\section{Risk Factors for Strep. agalactiae Infection at the Quarter Level}

Table 6 summarizes the final model with only those risk factors that were significant for the presentation of Strep. agalactiae at the quarter level. Some of the factors that showed an association with the presence of SM at the quarter level showed a similar tendency with respect to Strep. agalactiae infection. The odds that infection was present increased with parity and stage of lactation $(P<0.01)$. Parity had a similar OR pattern for Strep. agalactiae as for SM. However, stage of lactation $(\geq 6 \mathrm{mo})$ appeared to have a stronger effect
$(\mathrm{OR}=5.7, P<0.01)$ for Strep . agalactiae compared with $\mathrm{SM}(\mathrm{OR}=3.5, P<0.01)$. Manual milking was a significant risk for Strep. agalactiae $(\mathrm{OR}=5.4, P<$ $0.01)$.

Breed showed no association with Strep. agalactiae infection $(P=0.10)$. However, the role of breed as a confounder was investigated by fitting models for Strep. agalactiae infection with and without breed included. None of the coefficients for the other variables changed substantially when breed was excluded, so we concluded that any confounding effect of breed was minimal. Biologically plausible interactions of predictor variables were assessed and found to be nonsignificant. For

Table 5. Final logistic regression model assessing the effect of selected herd and cow variables on the probability for quarters to have subclinical mastitis (SCC $\geq 200,000$ cells $/ \mathrm{mL}$ ) ( $\mathrm{n}=53,030$ observations)

\begin{tabular}{|c|c|c|c|c|}
\hline Variable & Odds ratio & SEM & $P$-value & $95 \%$ CI \\
\hline Breed & & & $0.02^{1}$ & \\
\hline Holstein & Referent & & & \\
\hline Other breeds and crossbreed & 0.73 & 0.09 & 0.02 & $0.56-0.95$ \\
\hline Lactation month & & & $<0.01^{1}$ & \\
\hline 1 & Referent & & & \\
\hline 2 & 1.25 & 0.08 & $<0.01$ & $1.09-1.44$ \\
\hline 3 & 1.74 & 0.14 & $<0.01$ & $1.47-2.05$ \\
\hline 4 & 2.01 & 0.18 & $<0.01$ & $1.67-2.42$ \\
\hline 5 & 2.48 & 0.24 & $<0.01$ & $2.0-3.02$ \\
\hline$\geq 6$ & 3.51 & 0.25 & $<0.01$ & $3.03-4.07$ \\
\hline Parity & & & $<0.01^{1}$ & \\
\hline 1 & Referent & & & \\
\hline 2 & 1.57 & 0.17 & $<0.01$ & $1.25-1.98$ \\
\hline 3 & 2.41 & 0.25 & $<0.01$ & $1.95-2.97$ \\
\hline 4 or more & 3.40 & 0.44 & $<0.01$ & $2.61-4.44$ \\
\hline \multicolumn{5}{|l|}{ Adequate cleaning of udder } \\
\hline No & Referent & & & \\
\hline Yes & 0.78 & 0.06 & 0.01 & $0.66-0.94$ \\
\hline
\end{tabular}

${ }^{1}$ Overall $P$-value for categorical variable. 
Table 6. Final logistic regression model assessing the effect of selected herd and cow variables on the probability of quarters to have Streptococcus agalactiae infection ( $\mathrm{n}=55,411$ observations)

\begin{tabular}{lcccc}
\hline Variable & Odds ratio & $\mathrm{SE}$ & $P$-value & $95 \%$ CI \\
\hline Days in lactation & & & $<0.01^{1}$ & \\
Month 1 & Referent & & & \\
Month 2 & 1.98 & 0.31 & $<0.01$ & $1.44-2.73$ \\
Month 3 & 3.23 & 0.58 & $<0.01$ & $2.23-4.68$ \\
Month 4 & 3.85 & 0.65 & $<0.01$ & $2.72-5.44$ \\
Month 5 & 4.14 & 0.64 & $<0.01$ & $3.01-5.68$ \\
Month 6 and above & 5.74 & 0.90 & $<0.01$ & $4.15-7.92$ \\
Parity & Referent & & $<0.01^{1}$ & \\
1 & 1.72 & 0.36 & 0.01 & $1.11-2.65$ \\
2 & 2.32 & 0.46 & $<0.01$ & $1.54-3.49$ \\
3 & 2.91 & 0.51 & $<0.01$ & $2.02-4.18$ \\
4 or more & & & $<0.01^{1}$ & \\
Type of milking & Referent & & & \\
Mechanical & 5.37 & 2.06 & $<0.01$ & $2.45-11.8$ \\
Manual & & & $0.025^{1}$ & \\
Postdipping & Referent & & & \\
$\quad$ Yes & 2.23 & 0.51 & $<0.01$ & $1.39-3.59$ \\
No or inadequate & & & & \\
Adequate cleaning of udder & Referent & & & \\
No & 0.71 & 0.08 & $<0.01$ & $0.55-0.91$ \\
Yes &
\end{tabular}

${ }^{1}$ Overall $P$-value for categorical variable.

example, the interaction between proper teat disinfection and good teat cleanliness before milking was also examined, but no significant interaction was found $(P$ $=0.69 ;$ data not shown). The Hosmer-Lemeshow test indicated a good fit of the model $(P=0.3)$.

\section{DISCUSSION}

This study had several strengths and limitations. In retrospect, the design chosen for this study was not optimal for the evaluation of herd-level mastitis risk factors. The study would have had much more power to evaluate herd-level effects if a cross-sectional study involving many more herds had been used. However, the dynamics of mastitis in this dairy region were not well known before the study and we were uncertain if a cross-sectional study (with a single sampling in each herd) would adequately reflect the mastitis situation in the herd. Consequently, we used a convenience sample of 37 herds (of 3,049 herds present in the region) that were considered good examples of the specialized dairy herds in the region. As a result of the relatively low power of the study, only herd-level factors with a large effect on the prevalence of mastitis would have been detected.

The longitudinal study design used did provide some additional insights into mastitis in this region. We observed that the population of cows in the study was very dynamic for several reasons. Producers sold and bought cows frequently due to business opportunities or the need to raise or reduce the milk production to accomplish quotas set by the processor. Producers rarely knew the mastitis status of the cows they purchased (testing for mastitis before purchase was rarely done), nor did they quarantine new purchases.

Herd management practices and regional distributions from census data were used as benchmarks to ensure that the participant herds were good examples of dairy herds in the High Plains region of Colombia. However, extrapolation of the results, including prevalence estimates, beyond the 37 herds sampled and the region studied should be done with caution. The Survey command in Stata version 12.0 (StataCorp, 2011) was used in the data analysis for several reasons. First, the variance linearization procedure used allows for the simultaneous evaluation of both cow-level and herdlevel risk factors (while accounting for the repeated samplings within a cow), with appropriate standard error estimates. Second, it allows of incorporation of sampling weights into all analyses to correctly account for the probability of a herd being sampled within a municipality.

This study was designed to identify major risk factors associated with SM in one of the main milk production areas of Colombia in which manual milking still prevails over mechanical milking. In 4 of the 6 selected municipalities in the study sample, more than $90 \%$ of the herds were manually milked. In the remaining 2 municipalities, manual milking is used in 78 and $69 \%$ of herds, respectively (Ramírez et al., 2009). In this study, $81 \%$ of herds were manually milked. However, only $66 \%$ of all quarter-level observations were from cows milked manually because the average herd size was larger for machine milked herds. 
Access to automated SCC is limited in the region and the authors have previously determined that CMT had a sensitivity of $82 \%$ and a specificity of $97 \%$ for determining if a quarter had SM (SCC $\geq 200,000$ cells/ $\mathrm{mL}$ ) (Ramírez et al., 2010). The percentage (14.7\%) of quarters with CMT $\geq 1$ found in this study (data not shown) was less than the $19.9 \%$ found in another study in Antioquia (Trujillo et al., 2011). Both of these values are much lower than the 34.4 and $48.9 \%$ CMT $\geq 1$ observed in studies in Altiplano Cundi-Boyacense and the savannah of Bogota, respectively (Calderon and Rodríguez, 2008; Pinzon et al., 2009).

The major types of pathogens isolated in this study were contagious, with Strep. agalactiae accounting for $34.4 \%$ of all positive milk sample isolates. Similar results were found previously in Antioquia (47\%) in San Pedro de los Milagros municipality, and in the savannah of Bogota (44.9\%; Ramírez et al., 2001; Rodríguez, $2006)$. At the herd level, a high prevalence $(42 \%)$ of Strep. agalactiae was also reported in a stratified random sample of cooling tanks from various regions of Colombia (Keefe et al., 2011). The quarter-level geometric mean SCC reported by Djabri et al. (2002) was 357,000 and 857,000 for quarters infected with Staph. aureus and Strep. agalactiae, respectively. Values in the current study were markedly higher. This may reflect the study design, wherein only quarters with elevated CMT were sampled, or a greater chronicity of infection within our study population. The relatively high proportion of major mastitis pathogens (e.g., Staph. aureus and Strep. agalactiae) over more minor pathogens such as CNS is also reflective of the study design. Because quarters were prescreened by CMT, it is likely that infections with mild to moderate SCC responses were underrepresented in the prevalence data.

The relatively high percentage of quarters and cows affected with SM, together with the predominance of contagious bacteria such as Strep. agalactiae, Corynebacterium spp., and Staph. aureus, could be related to some shortcomings in important aspects of the milking routine. Manual milking was observed as a risk for infection with Strep. agalactiae (OR 5.4) compared with mechanical milking. The udder is a well-documented reservoir of infection for other cows (Pyörälä, 1995), and infection could be transmitted by the milker's hands in an improper milking routine. Coagulase-negative staphylococci were the second most common group of bacteria in order of frequency found in this study. Similar results were obtained in studies conducted in Colombia (Ramírez et al., 2001; Rodríguez, 2006) and Finland (Taponen et al., 2007). Prescreening with CMT would select higher SCC quarters for SCC and bacteriologic testing. It is likely that that some of the CMT-negative samples that were not analyzed at the laboratory could have been infected with CNS or other pathogens, resulting in a lower apparent prevalence of these low to moderate SCC producers. In this study, $30.4 \%$ of the milk cultures performed on samples from quarters with SM showed no growth, a value slightly higher than the $24.1 \%$ reported by Calderon and Rodríguez (2008) and the $16.4 \%$ reported by Ramírez et al. (2001).

Because most management practices are at the herd level, with just 37 herds in the logistic regression analysis, only the most important factors influencing the prevalence of SM and Strep. agalactiae (i.e., factors with substantial between-herd variation and with a large effect) would be detected by this study. Some variables that we hypothesized to be important risks for SM and Strep. agalactiae infection were not significant in the final model. For example, hand prewashing and hand washing between cows were done in only 17 and $10 \%$ of the observations at milking, respectively, and neither variable was significant in the model. Similarly, adequate PMTD was practiced by $84 \%$ of herds and was a significant protective factor for Strep. agalactiae but not SM. Lack of variability between herds would lead to very limited power of this study to detect these herd-level risk factors.

Other breeds and crossbreed cows had a lower prevalence of SM compared with Holstein cows. However, breed did not have a significant effect in the final model for mastitis caused by Strep. agalactiae. The prevalence of SM and Strep. agalactiae increased with increasing parity and stage of lactation. The number of calvings and the stage of lactation have also previously been shown to be associated with mastitis (Breen et al., 2009). The milking process carries a risk for transfer of contagious pathogens (Neave et al., 1969). As the number of lactations and months since calving within lactation increase, the number of times that cows are exposed to the milking process also increases, creating a higher cumulative probability of exposure to contagious agents.

Although the proportion of cows with adequate premilking teat dip use was very low, starting the milking process with a properly cleaned udder (by other means) was a protective factor against SM and Strep. agalactiae infection. The effectiveness of PMTD in controlling major contagious intramammary pathogens has been well demonstrated (Neave et al., 1969). In this study, when producers did not use PMTD or used it inadequately (i.e., by using a not-recommended chemical type, improper concentration, or insufficient time of action in the teat), the risk of Strep. agalactiae infection increased $(\mathrm{OR}=2.2)$. This same effect was not observed with respect to SM. The lack of significance of this variable in SM protection could be due to the low 
power, given the small herd-level sample size and widespread use of PMTD. Because SM was defined by CMT and SCC, infections in this category may be associated with other bacteria (such as CNS or environmental pathogens) that are less affected by PMTD in addition to the major contagious organisms. Although PMTD appeared to be correctly done in most dairy herds, it had no effect on existing infections (i.e., persistence of existing subclinical infections) and, unless it is part of a complete contagious mastitis control plan, the disinfectants are unlikely to fully protect against contagious organisms.

\section{CONCLUSIONS}

We detected a high prevalence of SM at both the cow and quarter levels. The most common microorganisms isolated were contagious bacteria, and the highest frequency was for Strep. agalactiae. Factors associated with SM were Holstein breed, higher parity, later stage of lactation, and an unclean udder at the start of milking. Factors associated with subclinical mastitis caused by Strep. agalactiae were similar: Holstein breed, higher parity, greater month of lactation, and an unclean udder at the start of milking. Additionally, SM caused by Strep. agalactiae was associated with manual milking and inadequate PMTD. The results highlight the importance of poor hygiene practices in maintaining a high prevalence of udder infection by contagious organisms, particularly in manually milked herds.

\section{ACKNOWLEDGMENTS}

This research was funded by the Ministerio de Agricultura y Desarrollo Rural de Colombia (Bogotá, Colombia), Universidad de Antioquia (Medellín, Colombia), Cooperativa Colanta Ltda (Medellín, Colombia), and Federación de Asociaciones de Ganaderos (FAGA, Medellín, Colombia). The authors thank the Sustainability Project 2013-2014 (Estrategia de sostenibilidad CODI 2013-2014, University of Antioquia). Thanks to David Villar (Universidad de Antioquia) for his help in the translation of the manuscript.

\section{REFERENCES}

Breen, J. E., M. J. Green, and A. J. Bradley. 2009. Quarter and cow risk factors associated with the occurrence of clinical mastitis in dairy cows in the United Kingdom. J. Dairy Sci. 92:2551-2561.

Calderon, A., and V. Rodríguez. 2008. Prevalencia de mastitis bovina y su etiologia infecciosa en sistemas especializados en produccion de leche en el altiplano cundiboyacense (Colombia). Rev. Colomb. Cienc. Pecu. 21:582-589.

Djabri, B., N. Bareille, F. Beaudeau, and H. Seegers. 2002. Quarter milk somatic cell count in infected dairy cows: A meta-analysis. Vet. Res. 33:335-357.
Dohoo, I. R., and A. H. Meek. 1982. Somatic cell counts in bovine milk. Can. Vet. J. 23:119-125.

Dufour, S., A. Frechette, H. W. Barkema, A. Mussell, and D. T. Scholl. 2011. Invited review: Effect of udder health management practices on herd somatic cell count. J. Dairy Sci. 94:563-579.

Edmonson, A. J., I. J. Lean, L. D. Weaver, T. Farver, and G. Webster 1989. A body condition scoring chart for Holstein dairy cows. J. Dairy Sci. XX:68-78.

Fetrow, J., D. Mann, K. Butcher, and B. McDaniel. 1991. Production losses from mastitis: Carry-over from the previous lactation. J. Dairy Sci. 74:833-839.

Harmon, R. J. 1994. Physiology of mastitis and factors affecting somatic cell counts. J. Dairy Sci. 77:2103-2112.

Keefe, G., A. Ceballos, M. Jaramillo, M. Londoño, M. Chaffer, and M. Toro. 2011. Effects of Streptococcus agalactiae on the Columbian Dairy Industry. Pages 155-159 in Proc. 3rd Int. Symp. Mastitis and Milk Quality, St. Louis, MO. National Mastitis Council, Verona, WI, and American Association of Bovine Practitioners, Auburn, AL.

Kramer, E., D. Cavero, E. Stamer, and J. Krieter. 2009. Mastitis and lameness detection in dairy cows by application of fuzzy logic. Livest. Sci. 125:92-96.

MacFaddin, J. 2000. Biochemical Tests for Identification of Bacteria 3rd ed. Williams \& Wilkins, Baltimore, MD.

Neave, F. K., F. H. Dodd, R. G. Kingwill, and D. R. Westgarth. 1969 Control of mastitis in the dairy herd by hygiene and management. J. Dairy Sci. 52:696-707.

NMC (National Mastitis Council). 1999. Laboratory Handbook on Bovine Mastitis. Rev. ed. National Mastitis Council, Madison, WI.

Pinzon, A., F. Moreno, and G. Rodriguez. 2009. Efectos de la mastitis subclínica en algunos hatos de la cuenca lechera del Alto Chicamocha (departamento de Boyacá). Rev. Med. Vet. (Bogotá) 17:23-25.

Pyörälä, S. 1995. Staphylococcal and streptococcal mastitis. Pages 143-148 in The Bovine Udder and Mastitis. M. Sandholm, T. Honkanen-Buzalski, L. Kaartinen, and S. Pyörälä, ed. Gummerus, Jyväskylä, Finland.

Ramírez, N., J. Cerón, M. Jaramillo, L. Palacio, and O. Arroyave. 2010. Diagnóstico de mastitis en el Norte de Antioquia. Pages 69 78 in Proc. VII Seminario Internacional Competitividad en Carne y Leche. Colanta, Medellín, Colombia.

Ramírez, N., G. Gaviria, O. Arroyave, and B. Sierra. 2001. Prevalencia de mastitis en vacas lecheras lactantes en el municipio de San Pedro de los Milagros, Antioquia. Rev. Colomb. Cienc. Pecu. 14:76-87.

Ramírez, N., M. Olivera, O. Arroyave, L. Palacio, M. Jaramillo, and J. Cerón. 2009. Caracterización de los sistemas de ordeño en granjas lecheras de seis municipios del altiplano norte del departamento de Antioquia, Colombia. Page 416 in Proc. X Encuentro Nacional de Investigadores de las Ciencias Pecuarias. Universidad de Antioquia, Medellín, Colombia.

Rodríguez, G. 2006. Comportamiento de la mastitis bovina y su impacto económico en algunos hatos de la Sabana de Bogotá, Colombia. Rev. Med. Vet. (Bogotá) 12:35-55.

Rodríguez, G., D. Contreras, and M. Ordoñez. 2002. Caracterización de la mastitis bovina en el Valle de Ubaté. Rev. Med. Vet. (Bogotá) 2:57-66.

StataCorp. 2011. Stata Statistical Software. Release 12. StataCorp LP, College Station, TX.

Taponen, S., J. Koort, J. Bjorkroth, H. Saloniemi, and S. Pyorala. 2007. Bovine intramammary infections caused by coagulase-negative staphylococci may persist throughout lactation according to amplified fragment length polymorphism-based analysis. J. Dairy Sci. 90:3301-3307.

Trujillo, C., A. Gallego, N. Ramírez, and L. Palacio. 2011. Prevalence of mastitis in dairy herds in Eastern Antioquia. Rev. Colomb. Cienc. Pecu. 24:11-18.

Winn, W., S. Allen, W. Janda, E. Koneman, G. Procop, P. Schrenckenberger, and G. Woods. 2006. Koneman's Color Atlas and Textbook of Diagnostic Microbiology. 6th ed. Lippincott Williams \& Wilkins, Baltimore, MD. 